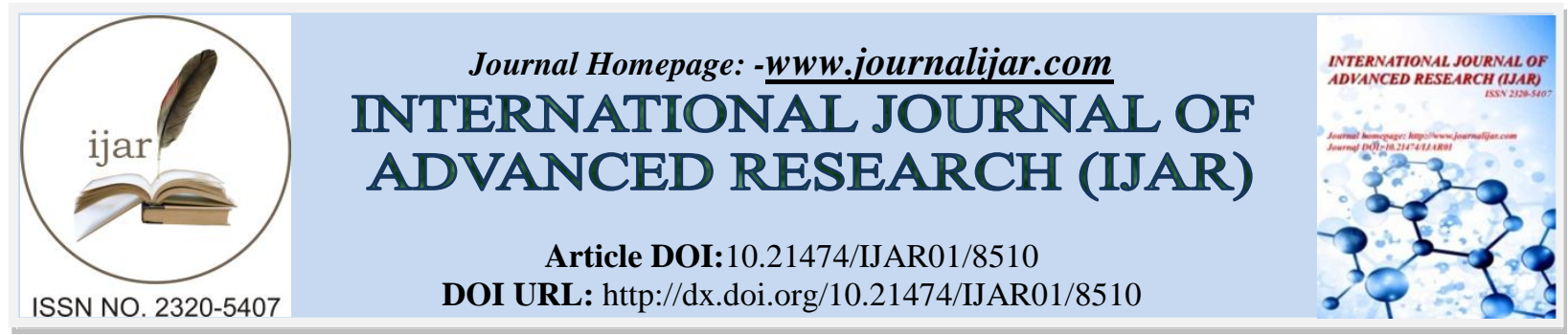

RESEARCH ARTICLE

\title{
FIRE SIMULATION APPLICATION BASED ON WIND DIRECTION USING CELLULAR AUTOMATA METHOD FOR WEB BASED FIRE REPORTING SYSTEM.
}

Ruddy J Suhatril ${ }^{1}$, Matrissya Hermita ${ }^{2}$ and Muhammad Fikri ${ }^{3}$.

1. Faculty of Industrial Technology, Gunadarma University.

2. Faculty of Psychology, Gunadarma University J1. Margonda Raya No. 100, Depok 16424, Jawa Barat.

\section{Manuscript Info}

Manuscript History

Received: 05 December 2018

Final Accepted: 07 January 2019

Published: February 2019

Applications, Simulation, Fire, Cellular,
Keywords: Automata, Web.

\begin{abstract}
The risk of fire can be decreased by following the fire occurrence and foreseeing the progress by time meaning. By simulated the extensive fire location using wind direction might help firefighters to managed and strategically made a decision in overcoming fires. Thus, there is an urge to provide reporting system to overcome the fire by using the website as an information receiver fire report which utilize downwind information simulation to locate fire as well as predict the extent fires location. This application creation phase starting from problem analysis, design, implementation and testing. This application uses cellular automata method for simulating the extent of fire by the wind. The testing process simulation using the home address location of the point the author is the area of East Jakarta with the simulation results of wind direction to the northwest with wind speeds at the location point of $7.7 \mathrm{KM} /$ Hour. This application was built using software laravel for website creation and use programming languages php, javascript and html. This Web application can run properly in the browser. This application was built using software laravel for website creation and use programming languages php, javascript and html. This Web application can run properly in the browser. This application was built using software laravel for website creation and use programming languages php, javascript and html. This Web application can run properly in the browser.
\end{abstract}

Copyright, IJAR, 2019, All rights reserved.

\section{Introduction: -}

According to The National Disaster Management Agency of Indonesia (BNPB) there was 352 residential fires occurred that can be considered as disastrous fire in 2018. However, the risk of fire can be increased by following the progress and development progress in a mean time. It can add a denser population, industrial or residential development, development of urban office buildings and so on that can lead to insecurity and panic when the fire so that the solution and the handling is needed to overcome the problems that could occur in the future (BNBP, 2018)

The development of technology can be a solution in helping issues, especially with the use of the internet is a medium to convey particular information, the easier the interaction and exchange of information on the spot. This indicates that the Internet has a great potential to be used as a means of communication and information that is reliable and easily accessible into extent through website utilizing. 
Website or who are familiar with the term web site is one of the technological breakthroughs that affect human life. Currently the website could also be one of the solutions to overcome the fire, is one of them as a media receiver fire report information. Fire report information may include the full address, photograph, simulation downwind of the fire location and so on. All that can help firefighters in performing their duties for fire-fighting. Therefore, we need a system that can help in overcoming the fire by using a web receiver of information that one of the fire information can help ie downwind simulation of the fire location.

Simulation of wind direction in the form of a picture spread of a fire by the wind, which can be integrated with maps and displays information on the wind direction along with the speed of a point location of fire can enable staff to take a position or decision to tackle fires solution was happening.

The purpose of this study was to develop a website to help firefighters in receiving the fire report, assist firefighters in receiving information about wind direction and wind speed from the scene of the fire and Provide information to officers of firefighters in the form of a picture simulating the spread of fire by directions wind from the point of the fire location using cellular automata

\section{Literature Review:-}

\section{Simulations}

Simulation is considered as an alternative to solve problems that exist in the real world by managing uncertain problems and length of time that cannot be calculated. It can also affect what is real, the surroundings or the process. For the simulation, there are three main methods used are Discrete Event Simulation (DES), System Dynamics (SD) and Agent Based Simulation (ABS).

Discrete Event Simulation (DES) is a simulation technique most used in Operational Research. As its name which shows a model of the process as a series of discrete events. DES system is usually considered as a queuing network and servers, as in the system which can be seen in Figure 1.

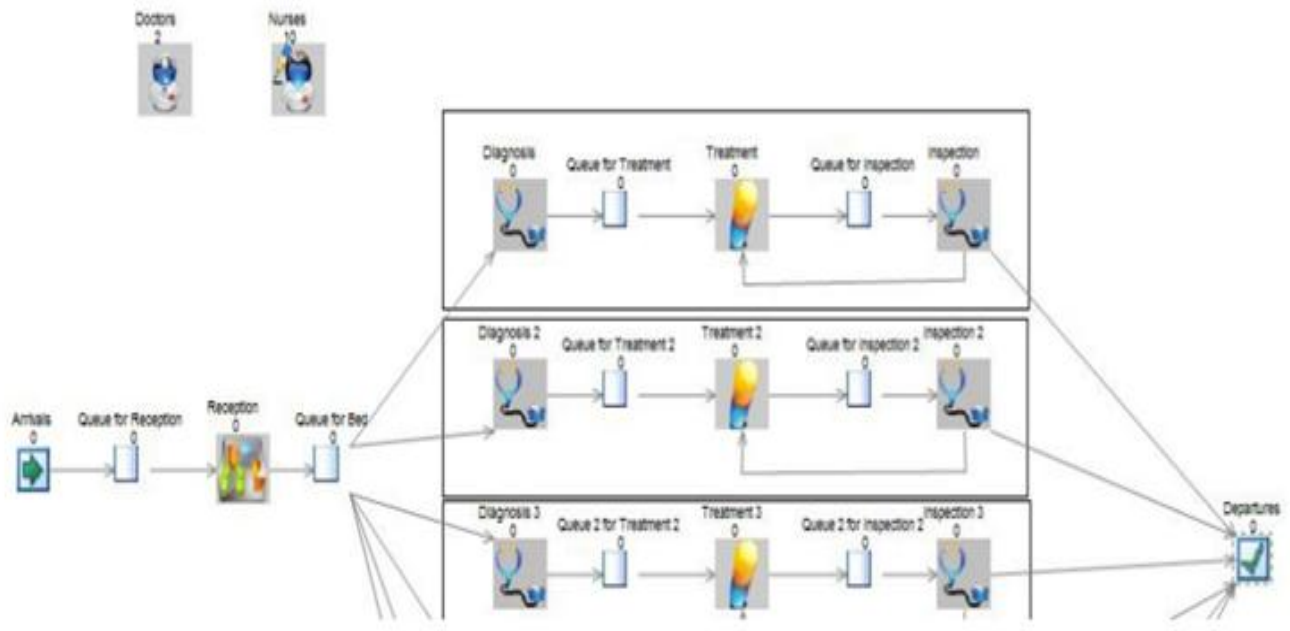

Figure 1: -Part of the model DES [3].

System Dynamic(SD) is a simulation technique that focuses on the flow around the network rather than the individual behaviour of the entity and has 3 main objects that can be used namely stocks, streams and delays, therefore the system dynamics model can be said as a stock network, flow and delay depend on several constants general. The SD model can be seen in Figure 2 . 


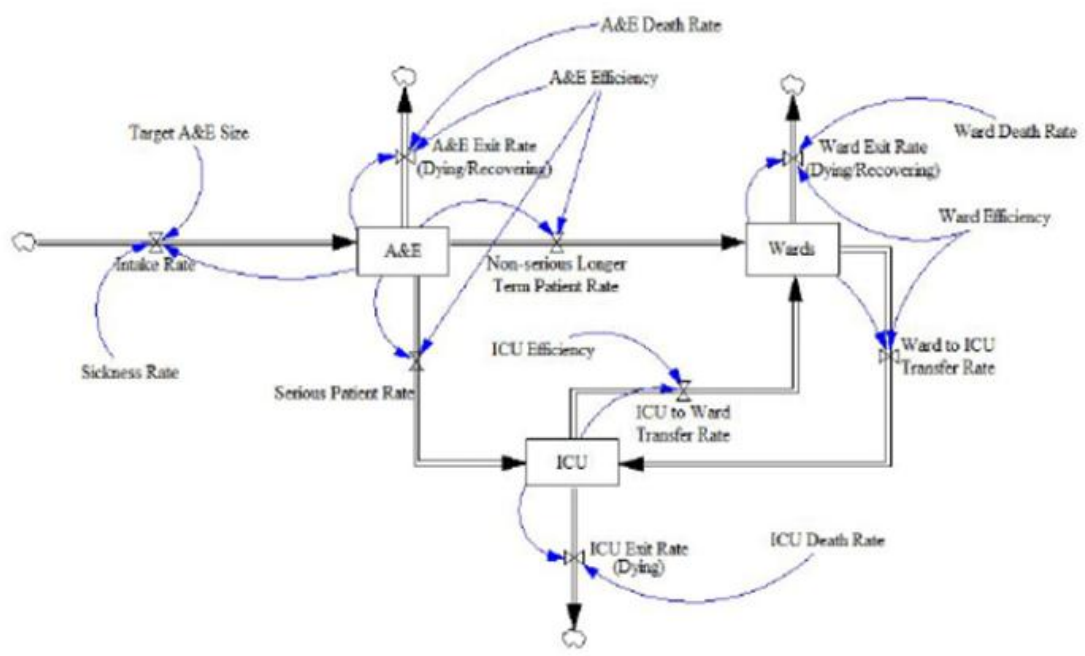

Figure 2: -Part of the Model SD

Agent Based Simulation (ABS) is a form or model of the $\mathrm{n} x \mathrm{n}$ grid that contains cells and each cell can be "alive" or "dead". Then determine or prepare an initial state for the process where each cell has results with the following rules:

1. Living cells as $\mathrm{X}$ and at most neighbor living cells that will live in the next step as $\mathrm{Y}$.

2. Cells die properly, but life will come to life in the next step as Z.

3. If not, the cell will die from loneliness or overcrowding in the next step.

Here " Neighbour " are cells adjacent to the cell in question, including diagonal. In addition, $\mathrm{X}, \mathrm{Y}$, and $\mathrm{Z}$ values can also be changed during the process, for example Figure 2.3 shows some of these effects.
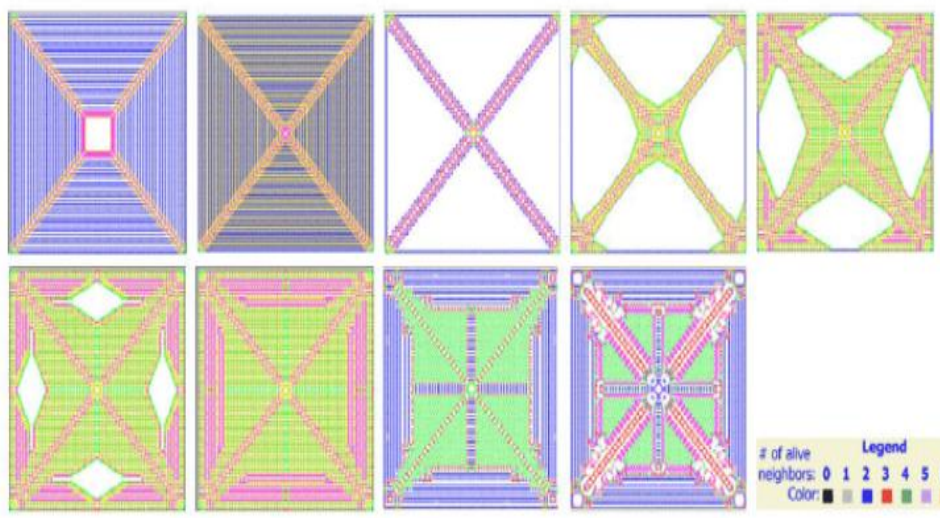

I of alive Legend

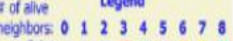

Figure 3: -The pattern of variation of Game Of Life.

\section{Cellular Automata}

Cellular automata (CA) is an identical set of cells by performing a discrete dynamic system process or having a predetermined rule process. Therefore, the cell collection has a changing state every time step is discrete based on deterministic rules (Digilib ITB, 2018) However, Mobile automata have the following characteristics:

1. Sel lives on the grid.

2. Each cell has a state (can have conditions as "on" and "of" or "live" and "die").

3. Every cell has an environment. 


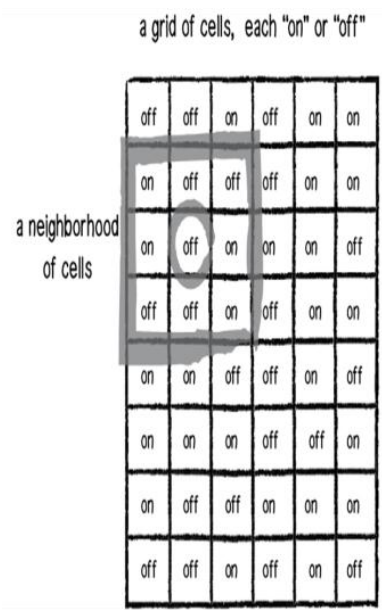

\section{Wind and Wind Speed}

Figure 4: -Cellular Automata (Shiffman, 2012)

Wind is moving air due to the rotation of the earth and the difference in air pressure in the vicinity. The wind moves from places of high pressure to low air pressure. Wind speed is the distance of the wind or air movement per unit time and expressed in meters per second $(\mathrm{m} / \mathrm{s})$, kilometers per hour $(\mathrm{km} / \mathrm{h})$ and miles per hour $(\mathrm{mi} / \mathrm{h})($ Pangestu, 2014)

\section{Beaufort Scale List}

Wind Speed at a Standard Height of 10 Meters Above Flat Land

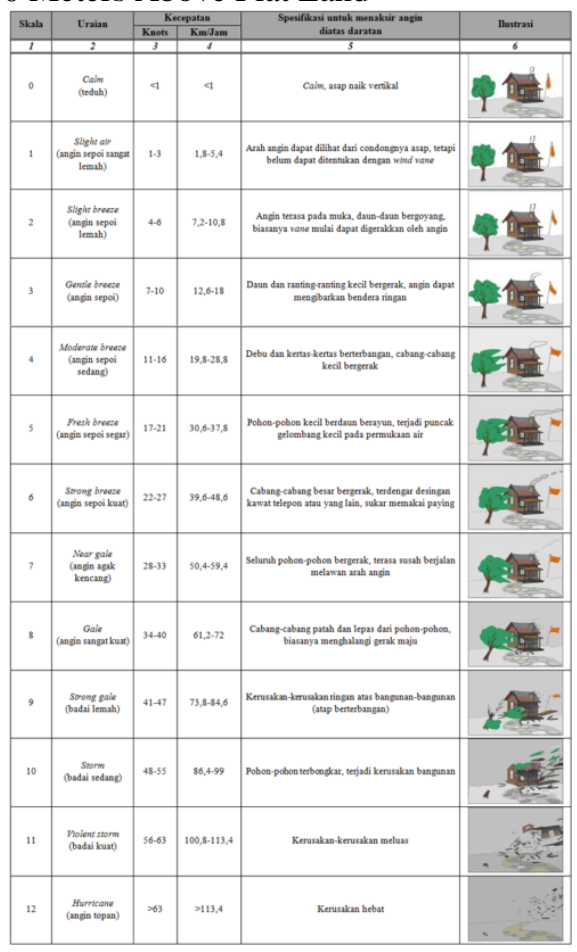

Figure 5: -Beaufort Scale

\section{Standards for web page load time}

Speed page basically refers to the length of time in which a webpage or downloaded media content from the server hosting the web site and displayed to the requesting web browser. Page load time is the duration between clicking links and display the entire content of the web page in the browser that requested (Cyst, 2018).

There are three core aspects required to understand the speed of the page in the context of user experience and performance of the website: 
1. Display the time used to send the requested material in conjunction with the accompanying HTML content to the browser.

2. Response browser to request the page loading.

3. The end-user view as requested by the requested web page in the browser is the most important final size of the page loading speed (Cyst, 2018)

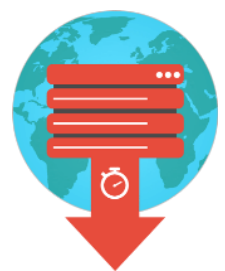

\section{Methodology: - \\ Data Processing}

The data in this study is used to get his point the location of the fire report in which location information will be processed to be sent to the API Accuweather in order to obtain an index of her mouth contains information to get the wind direction and wind speed and point location will be in the process also to illustrate simulating the movement of the spread of fire by the wind direction using cellular automata.

\section{Flowchart}

Flowchart or program flow charts describe the algorithm in detail by using symbols that represent each of the program flow and allows the reader to know the way the program is structured. Flowchart shows the process flow simulations explain how the passage of fire based on the wind direction the web is made. In this application inprocess flow for the wind direction is the simulation process using cellular automata method.

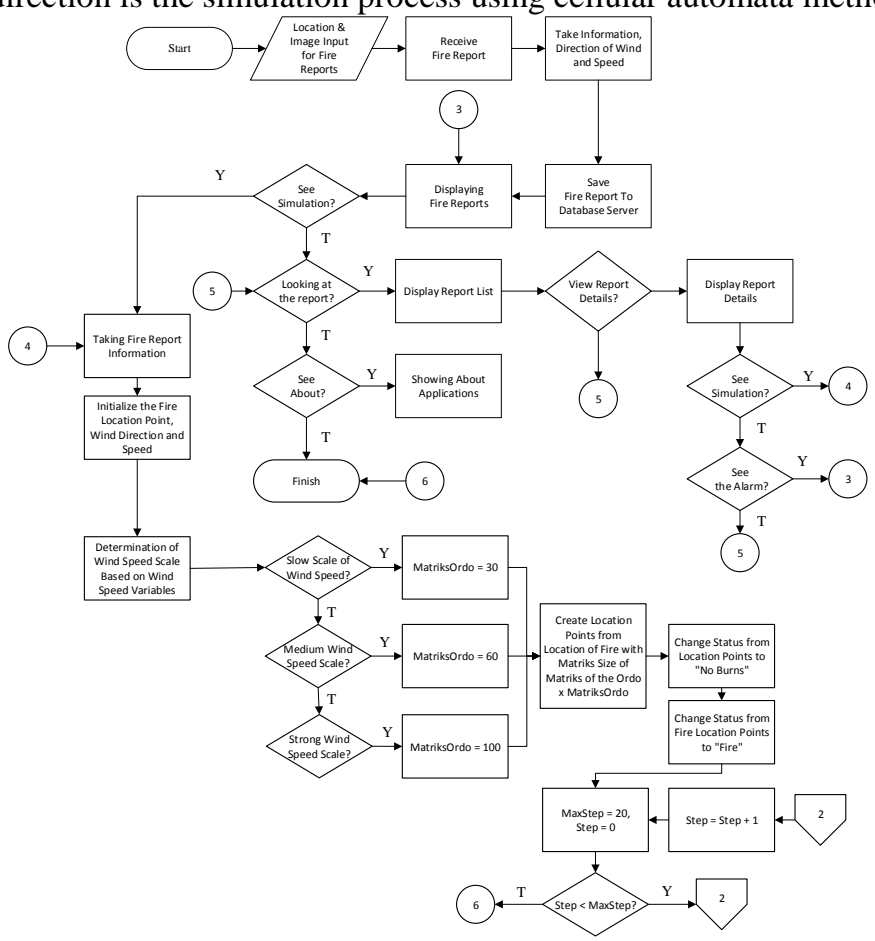

Figure 7: -Flowchart Perform Process Simulation

\section{Flow chart Cellular Automata}

Flowchart diagram showing the process flow continued from 5:12 point is in the process of celular automata method on the location of fires that have been received by the server from user reports. This automat cellular method describes the general process of checking the location of the fire so that it can display the simulated movements such as the spread of fire. To more clearly be seen in the picture. 


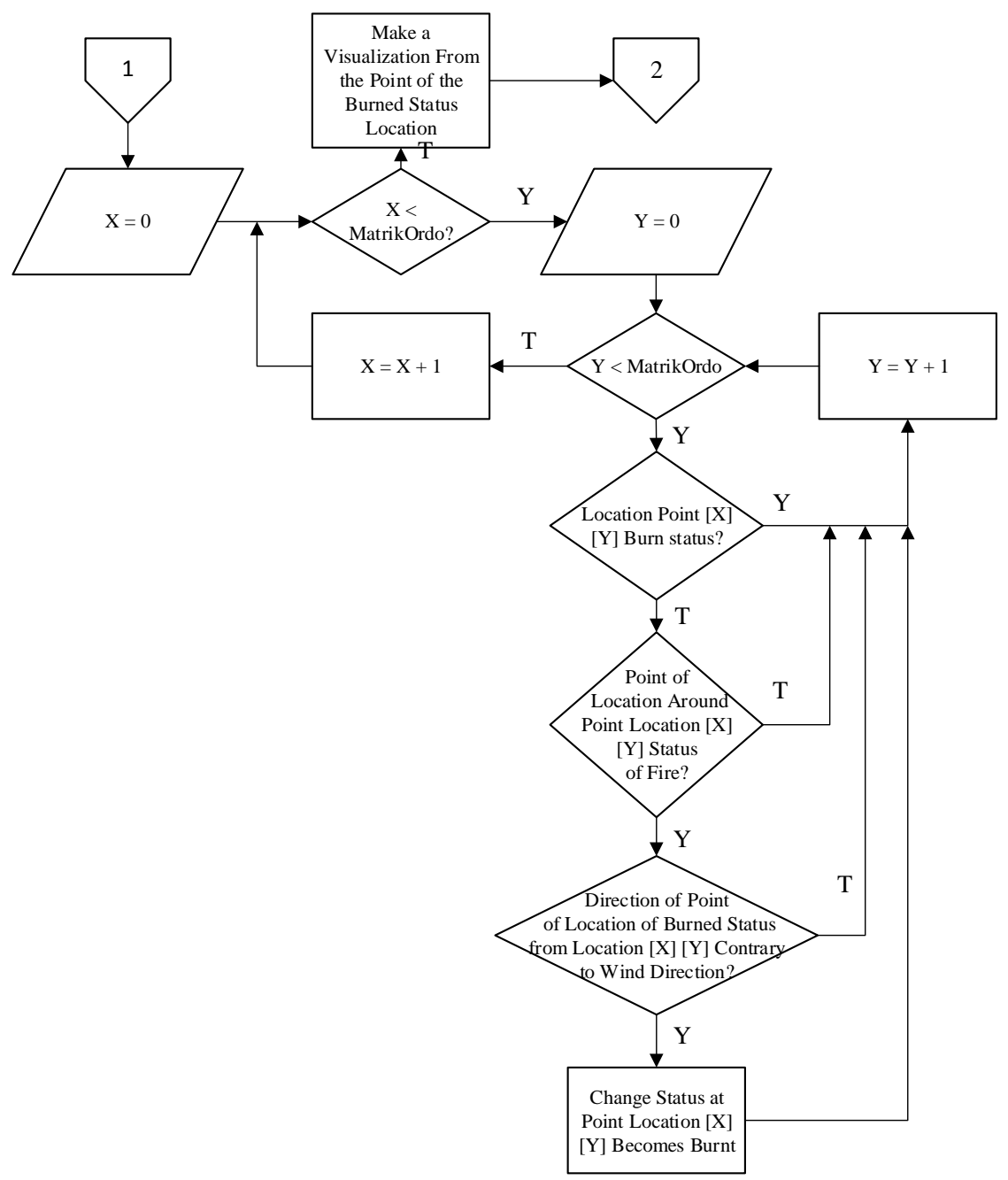

Figure 8:-Flowchart Perform Process Simulation

\section{Experiment and Result: -}

\section{Matrix Area for Simulation}

This function is made to make comprehensive matrix for the simulation of fire spread by wind to pick up information from the reports that have come in the form of information such as the full address. Here is the pseudocode makes extensive matrix for simulations: 


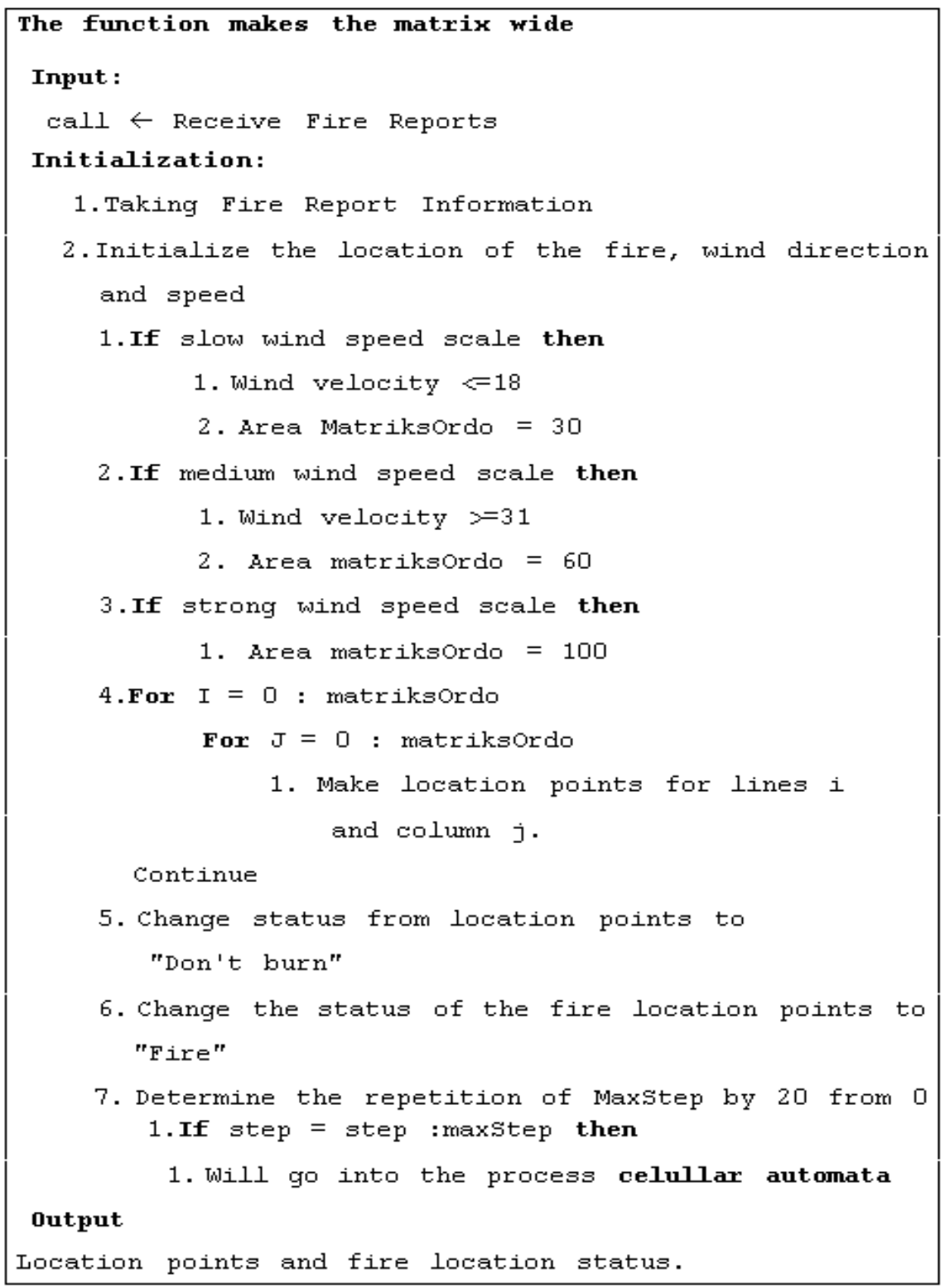

The above process starts with input fire report. After the initializing fire address information such as latitude and longitude. After the shot, then it will be sent to the url API Accuweather that which will be processed to obtain information about wind direction and speed. After getting information from the API AccuWeather then initializing the location of fire, wind direction and speed. Furthermore, the wind speed is used to get wind scale in the form of value matriksOrdo and make points the location of the fire location. Furthermore, changing the status of location points around being "not on fire" and the scene of the fire to be "on fire". Then determine the simulation iteration limit and will go into the process of cellular automata function.

\section{Cellular automata}

This function is made to run a simulation using cellular automata fire spread following is a pseudocode run the simulation: 


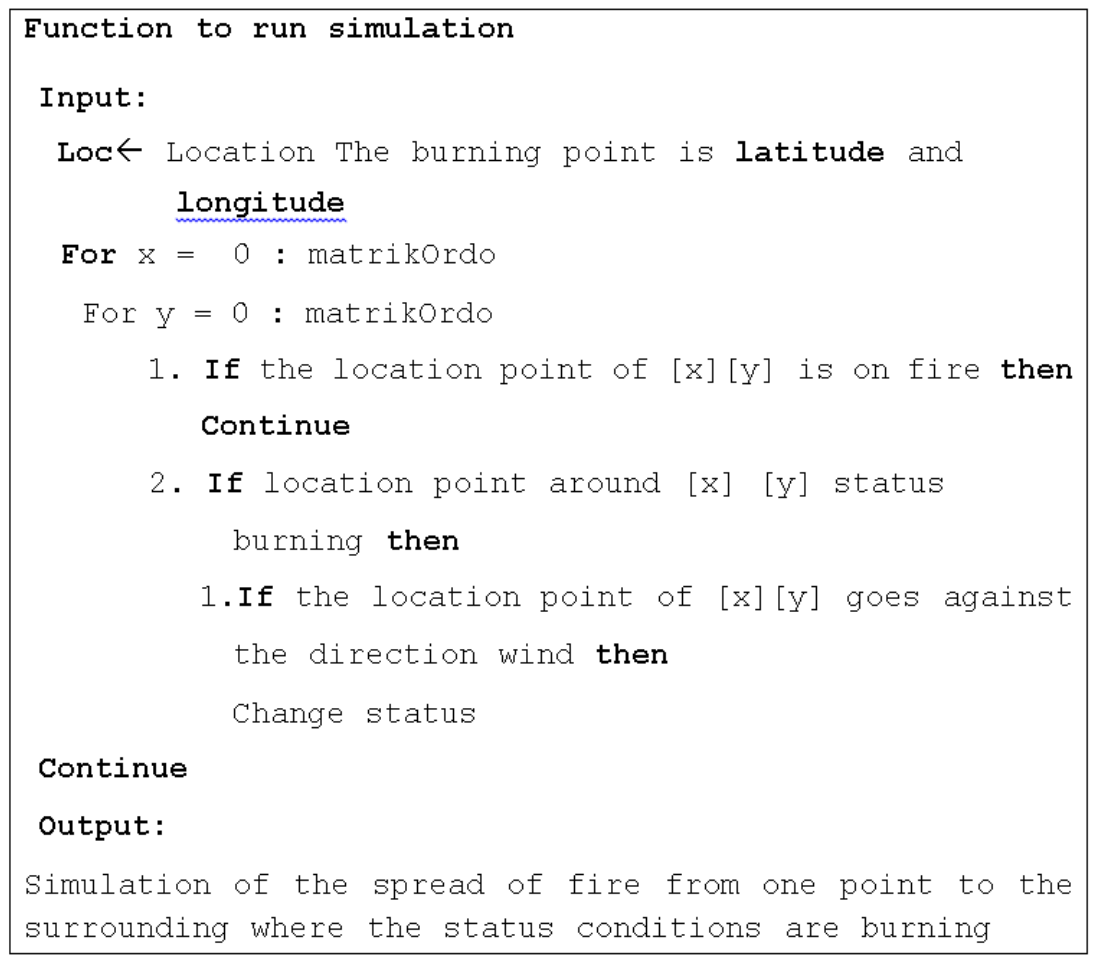

The above process starts with input the location of the fire in the form of latitude and longitude. After that for $\mathrm{x}$ are in the form of lines looping up to less than the value matrikOrdo acquired. Further into the looping column y will be for looping to less than the value matrikOrdo. After that there is the first condition is whether the value of point locations [x] [y] status on fire if yes then will check the next location and if not then it will go check the condition of the 2nd. Checking the condition of the 2nd ie whether point locations around [x] [y] status on fire? if yes then it will go to check the condition of the 3rd and if not will further check the next location. Checking the condition of all three, namely whether the location point $[\mathrm{x}][\mathrm{y}]$ the opposite direction of the wind? if yes then it will change the status to fire and if not then it will further check the location next to the limit matriksOrdo repetition columns.

\section{Test Simulation}

These include application testing, simulation testing on the website admin unit with a web browser.

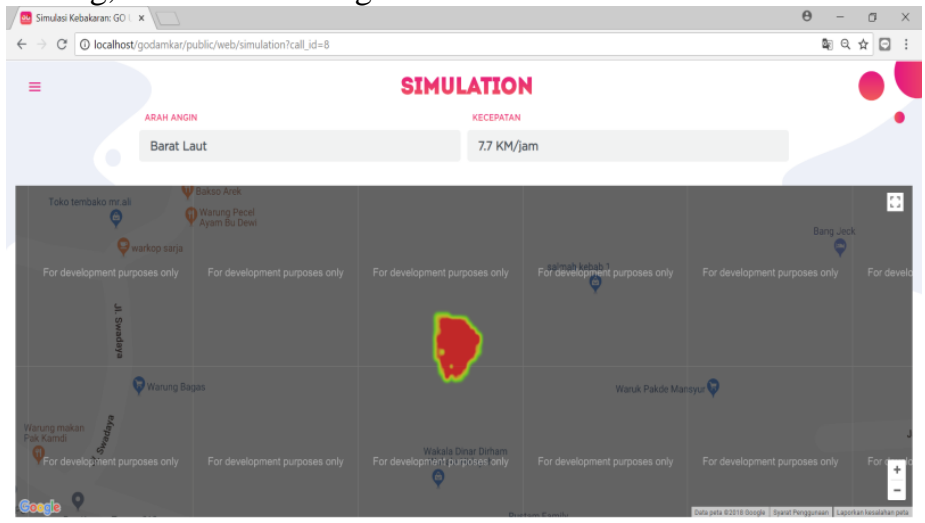

Figure 9: -Test Simulation

In the picture above is a view which illustrates the simulation of movements simulating the spread of fire by the wind direction according to the information obtained in the wind direction and the location of the report to show wind direction information along with its wind speed. In addition, the results of the trial to see the simulation can also help user's firefighters in taking attitude and good decisions. 
Table 1: -Simulation Test

\begin{tabular}{|c|c|c|c|}
\hline No & Region & Address & Test result \\
\hline 1. & $\begin{array}{c}\text { Jakarta } \\
\text { Timur }\end{array}$ & $\begin{array}{l}\text { J1.Swadaya No.26 } \\
\text { R.t O4/Rw o5 } \\
\text { Kode Pos: } 13930 \\
\text { Kecamatan :Cakung } \\
\text { Kelurahan: } \\
\text { Jakarta Timur }\end{array}$ & $\begin{array}{l}\text { 4. Waktu : } 12 / 8 / 2018 \\
\text { 5. Arah Angin : Barat Laut } \\
\text { 6. Kecepatan : } 7.7 \mathrm{~km} / \mathrm{jam}\end{array}$ \\
\hline 2 & $\begin{array}{c}\text { Jakarta } \\
\text { Timur }\end{array}$ & $\begin{array}{l}\text { J1. Swadaya No.26 } \\
\text { Rt O4/Rw o5 } \\
\text { Kode Pos: } 13930 \\
\text { Kecamatan :Cakung } \\
\text { Kelurahan: } \\
\text { Jakarta Timur }\end{array}$ & $\begin{array}{l}\text { 4. Waktu : } 27 / 7 / 2018 \\
\text { 5. Arah Angin : Barat Laut } \\
\text { 6. Kecepatan : } 5.8 \mathrm{~km} / \mathrm{jam}\end{array}$ \\
\hline 4 & $\begin{array}{c}\text { Takarta } \\
\text { Timur }\end{array}$ & $\begin{array}{l}\text { J1.Swadaya No.26 } \\
\text { Rt 04/Rw o5 } \\
\text { Kode Pos: } 13930 \\
\text { Kecamatan :Cakung } \\
\text { Kelurahan: } \\
\text { Jakarta Timur }\end{array}$ & $\begin{array}{l}\text { 4. Waktu : } 24 / 7 / 2018 \\
\text { 5. Arah Angin : Barat } \\
\text { 6. Kecepatan : } 6.4 \mathrm{~km} / \mathrm{jam}\end{array}$ \\
\hline
\end{tabular}

\section{Conclusions: -}

The process of receiving reports to retrieve report information from users, retrieve weather using the accuwater API is a reference for obtaining information on wind direction and speed from the location of the fire. The simulation process with the function of initializing the location of the fire, wind direction, and speed, map initialization function, determina- tion function wind speed scale based on wind speed variables clearly shows the scale of the fire process properly and correctly. From the results of simulation tests conducted on one fire area in east jakarta shows the results of testing the wind direction and speed at different times of fire simulation run well and effectively. The test results have concluded that the average wind speed above $5 \mathrm{~km} /$ hour has been carried out for testing one location in the east jakarta area.

\section{References: -}

1. BNPB, 2018, Data Disaster Sire, http://geospasial.bnpb.go.id/pantauanbencana/data/datakbmukimall.php, Access Date: August 16, 2018.

2. BINUS 2010, Chapter 2 Basis Theory, http://thesis.binus.ac.id/doc/ Chapter 2 / 2010-2-00424-MTIF\% 20bab\% 202.pdf, Access Date: August 16, 2018.

3. Cyst. 2018. Beginner's Guide to Web Site Speed Optimization, https://kinsta.com/learn/page-speed/, Access Date: August 26, 2018.

4. Digilib.itb, 2011, Chapter 2 introduction cellular automata, http://digilib.itb.ac.id/files/disk1/450/jbptitbpp-gdldescawiday-22497-3-2011ta-2.pdf, Date of access: 16 August 2018.

5. Maidstone, Robert. 2012. Discrete Event Simulation, System Dynamics and Agent-Based Simulation: Discussion and Comparison, https://www.researchgate.net/publication/306157680_Discrete_Event_Simulation_System_Dynamics_and_Age nt_Based_Simulation_Discussion_and_Comparison, Access Date: August 26, 2018.

6. Pangestu, 2014, DESIGN AND ANEMOMETER BOWL WITH LABORATORY AND FIELD (CUP ANEMOMETER WITH DESIGN LABORATORY AND FIELD), http://eprints.undip.ac.id /45586/3/BAB_II.pdf, Access Date: August 16, 2018.

7. Shiffman, Daniel. 2012. The Nature of Code: Simulating Natural Systems with Processing, New York University: The Magic Book Project.

8. Staklimjambi, 2016, Beaufort scale, https://staklimjambi.blogspot.com/2016/04/skala-beaufort_10.html, Access Date: August 16, 2018. 